\title{
Stephanorhinus kirchbergensis (Jäger, 1839) (Mammalia, Rhinocerotidae) from European Russia: A new, detailed inventory of sites and referred material
}

\author{
Emmanuel M.E. Billia*
}

Independent Researcher

\begin{abstract}
This paper presents a status review of the fossil remains discovered in European Russia and assigned to Stephanorhinus kirchbergensis (Jäger, 1839). Similarly to other areas, this taxon appears rare in European Russia, despite its wide distribution. Furthermore, a large part of the S. kirchbergensis material reported in literature is presently untraceable in the Russian museum collections. In fact, from a total of twenty-one sites, the material is physically available from only three of them. In addition, the remains from Podosinik, previously not mentioned in literature, are reported here. The available material has been studied using descriptive morphological characters. This study follows a previous treatment of the related sites and material from Siberian Russia by the same author. Stephanorhinus is considered here as a synonym of Dicerorhinus.
\end{abstract}

Key words: Pleistocene, European Russia, Stephanorhinus kirchbergensis

\section{Introduction}

A literature review reveals twenty-one European Russian localities where remains ascribed to Stephanorhinus kirchbergensis (Jäger, 1839) were found. Unfortunately, available $S$. kirchbergensis remains are presently known from three localities only: Samara [8], Kurilovka [13], and Cherny Yar (or Nizhnee Zaymishche) [18] (numbers in square brackets are those given in the list of localities, for ease of reference throughout this text). To this list, the fragmentary hemimandible from Podosinik (? Volgograd region) [17] (unpublished material) must be added.

* Corresponding address: via Bacchiglione 3, 00199 Roma, Italy; E-mails: eme.billia@alice.it, e.billia@yandex.ru

Received: January 24, 2013; accepted: July 4, 2014 
Two other localities - Mysy Layshevsky [20/bis] and Nikol'skoe [21] - yielded remains previously assigned to $S$. kirchbergensis which must be assigned to other rhinoceros species (Coelodonta antiquitatis [Blumenbach, 1799] and Stephanorhinus cf. S. etruscus [Falconer, 1868], respectively).

The material from sixteen other localities is untraceable in the Russian museum collections. Among them, two occurrences ("Samara region" [9] and Khoroshevsky Island [10]) are probably due to errors and/or misidentifications. In at least three other cases, the remains are permanently lost (those from Vysokoe [1] and the Girey Quarry [19] were lost during World War II; those from the Tungus Peninsula [7] were destroyed in a fire).

Synonymy, taxonomical position, general as well as odontological characters, reconstructions of the species (those made by Flerov - Flerov et al. 1955 - and by Kozhamkulova - Kozhamkulova and Kostenko 1984), dispersal areal, probable area of origin, rarity of the species, phylogeny, biotopes of the Pleistocene Eurasian interglacial rhinoceros S. kirchbergensis - better known in Russia as "nosorog Merka" (literally, Merck's rhinoceros) - were discussed in detail in a previous work (Billia 2011). In the present paper, another reconstruction attempt (by $\mathrm{Yu}$ Chen 2010) is also proposed (Fig. 1). A preliminary, and not comprehensive, report on the S. kirchbergensis remains in Russian Federation has previously been presented by the author (Billia 2008a).

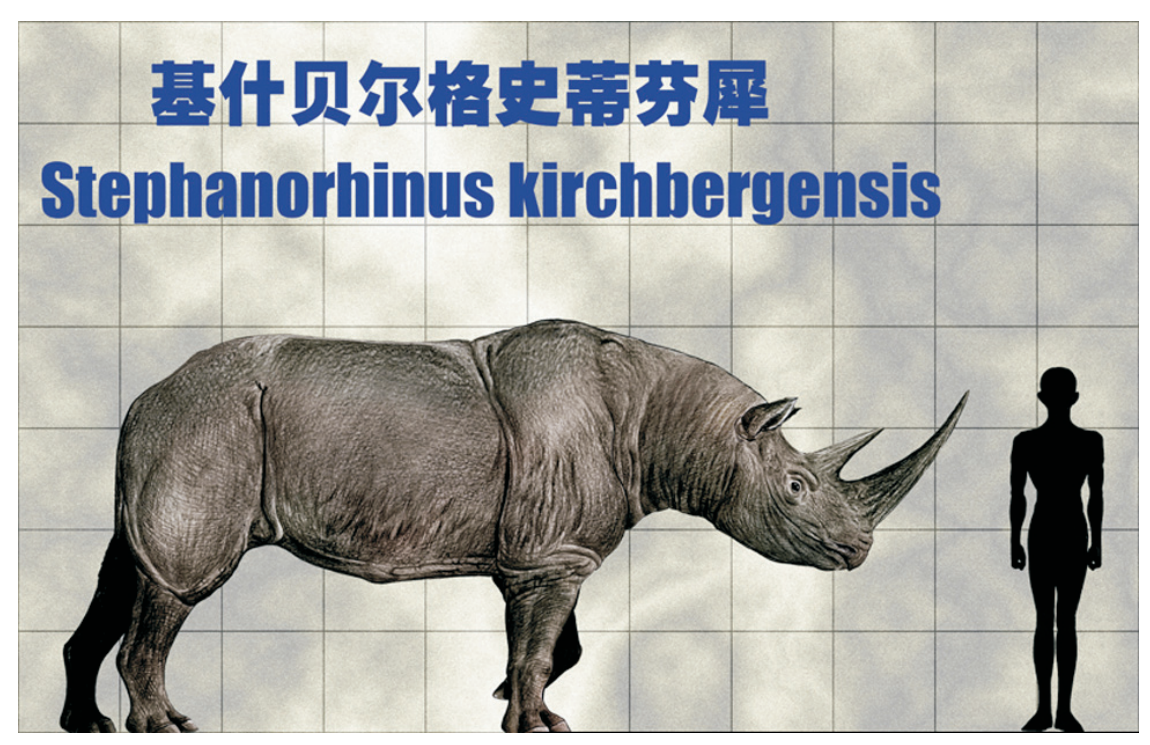

Fig. 1

Reconstruction of Stephanorhinus kirchbergensis (Jäger, 1839) after Yu Chen (2010, personal present; this illustration is used here through the courtesy of the artist, all rights reserved) 
The genus Stephanorhinus was first introduced by Kretzoi (1942) in honor of King Stephen I, the first king of Hungary.

\section{LIST OF THE EUROPEAN RUSSIAN LOCALITIES CITED IN THE TEXT}

(in alphabetical order; in brackets, their paragraph numbers used in the text)

Cheremukhova Krucha [16]

Cherny Yar [18]

Girey Quarry [19]

Klevenka-1 [11]

Klevenka-2 [12]

Khoroshevsky Island [10]

Khvalynsk (vide Khoroshevsky)

Kurilovka [13]

Malyutino [5]

Moscow-Volga Canal [3]

Mysy Layshevsky [20-20/bis]

Nikol'skoe [21]

Nizhnee Zaymishche (vide Cherny Yar)

Podol'sk [4]

Podosinik [17]

Rakhmanovka [14]

Rybinsk [2]

Samara City [8]

Samara Region [9]

Shchygry [6]

Tarasovka [15]

Tungus Peninsula [7]

Vysokoe [1]

\section{Acronyms}

AN KazSSR Academy of Sciences of Kazakh SSR, Alma-Ata (at present, National Academy of Sciences of Kazakhstan, Almaty)

AN SSSR USSR Academy of Sciences (at present, Russian Academy of Sciences [RAN])

GIN Institute of Geology, Russian Academy of Sciences, Moscow

GMM KGU Museum of Geology and Mineralogy, Kazan' State University, Kazan'

MIS Marine Isotope Stage 
PIN "YU.A. Orlov" (at present, "A.A. Borissyak") Paleontological

PMK Institute, Russian Academy of Sciences, Mos

RAN Rossiiskaya Akademya Nauk [Russian Academy of Sciences]

SOIKM Oblastnoy Istorichesky-Etnografichesky Muzey im. "P.V. Alabina" ["P.V. Alabin" Regional Historical-Ethnographic Museum], Samara

ZIN Zoological Institute, Russian Academy of Sciences, St. Petersburg

ZMSU Zoological Museum, Institute of Pedagogy, Smolensk State University, Smolensk

\section{Abbreviation}

n.n. unregistered specimen

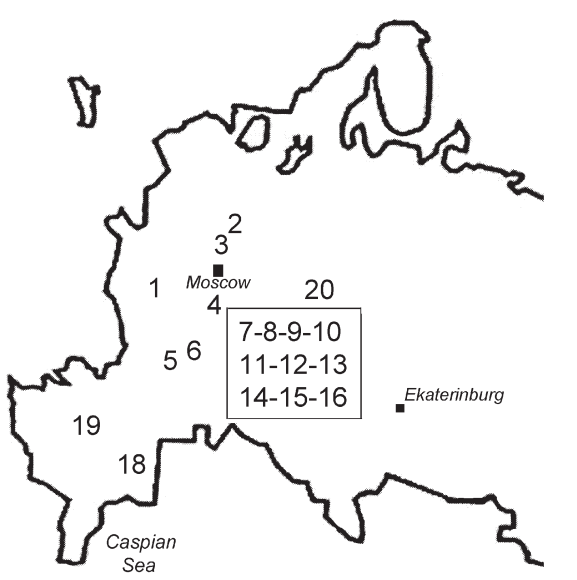

Fig. 2

Geographic localization of the sites on Russian-European territory where $S$. kirchbergensis (Jäger, 1839) remains have been found: 1 . Vysokoe 2. Rybinsk-3. Moscow-Volga Canal-4. Podol'sk -5 . Malyutino -6 . Shchygry -7 . Tungus Peninsula - 8. Samara City - 9. Samara Region - 10. Khoroshevsky Island (or Khvalynsk) - 11. Klevenka-1 - 12. Klevenka-2 - 13. Kurilovka - 14. Rakhmanovka - 15. Tarasovka - 16. Cheremukhova Krucha - 18. Cherny Yar (or Nizhnee Zaymishche) - 19. Girey Quarry - 20. Mysy Layshevsky

\section{S. KIRCHBERGENSIS (JÄGER) IN EUROPEAN RUSSIA Localities and material}

Figs 2 and 3 show the geographic localization of the sites in European Russia where $S$. kirchbergensis remains were found. Tables 1 and 2 give an overview of the 22 sites and the fossil remains, their inventory numbers, references, as well as the diagnoses and the present whereabouts of available remains. Measurements of the available $S$. kirchbergensis remains from four European Russian localities are given in Tables 3, 4 and 5. 


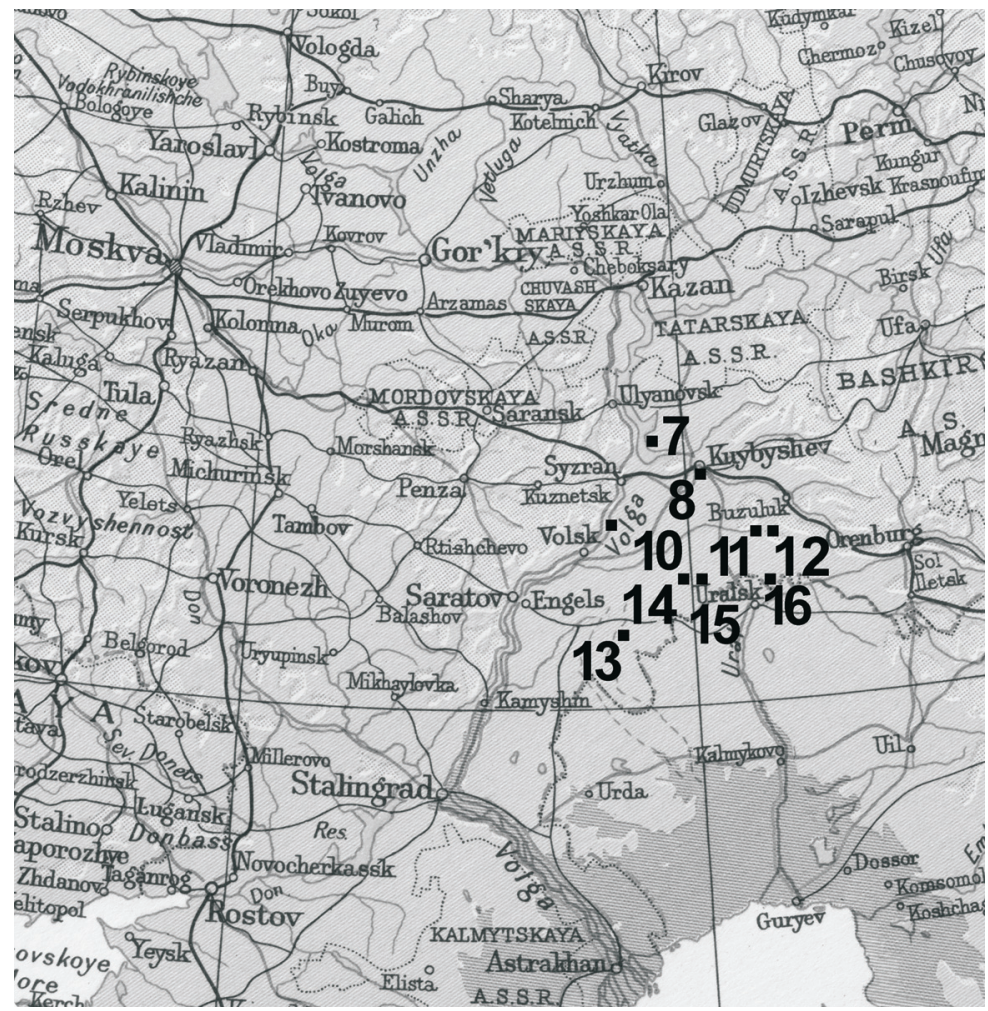

Fig. 3

Detail of the geographic localization of the Volga middle-lower course sites from 7 to 16 (within the rectangle in Fig. 2, except for the Site n. 9 [Samara Region]): 7. Tungus Peninsula - 8. Samara City - 10. Khoroshevsky Island (or Khvalynsk) -11 . Klevenka-1 - 12. Klevenka-2 - 13. Kurilovka - 14. Rakhmanovka - 15. Tarasovka 16. Cheremukhova Krucha

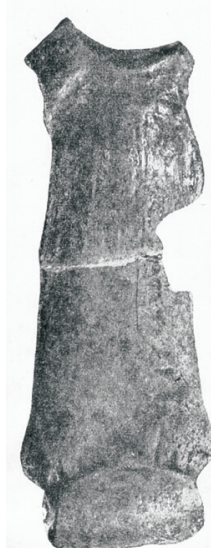

32

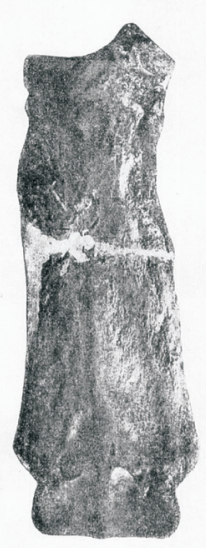

33

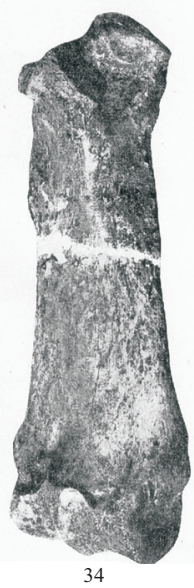

Fig. 4

Stephanorhinus cf. S. kirchbergensis (Jäger, 1839); Sheksna River near the "Trudovik" brick kiln (Rybinsk, Yaroslavl’ Region, European Russia); os metacarpale III, (32) cranial view, (33) caudal view, (34) latero-caudal view (ca $1 / 3$ natural sizes) (after Belyaeva, 1939a) 


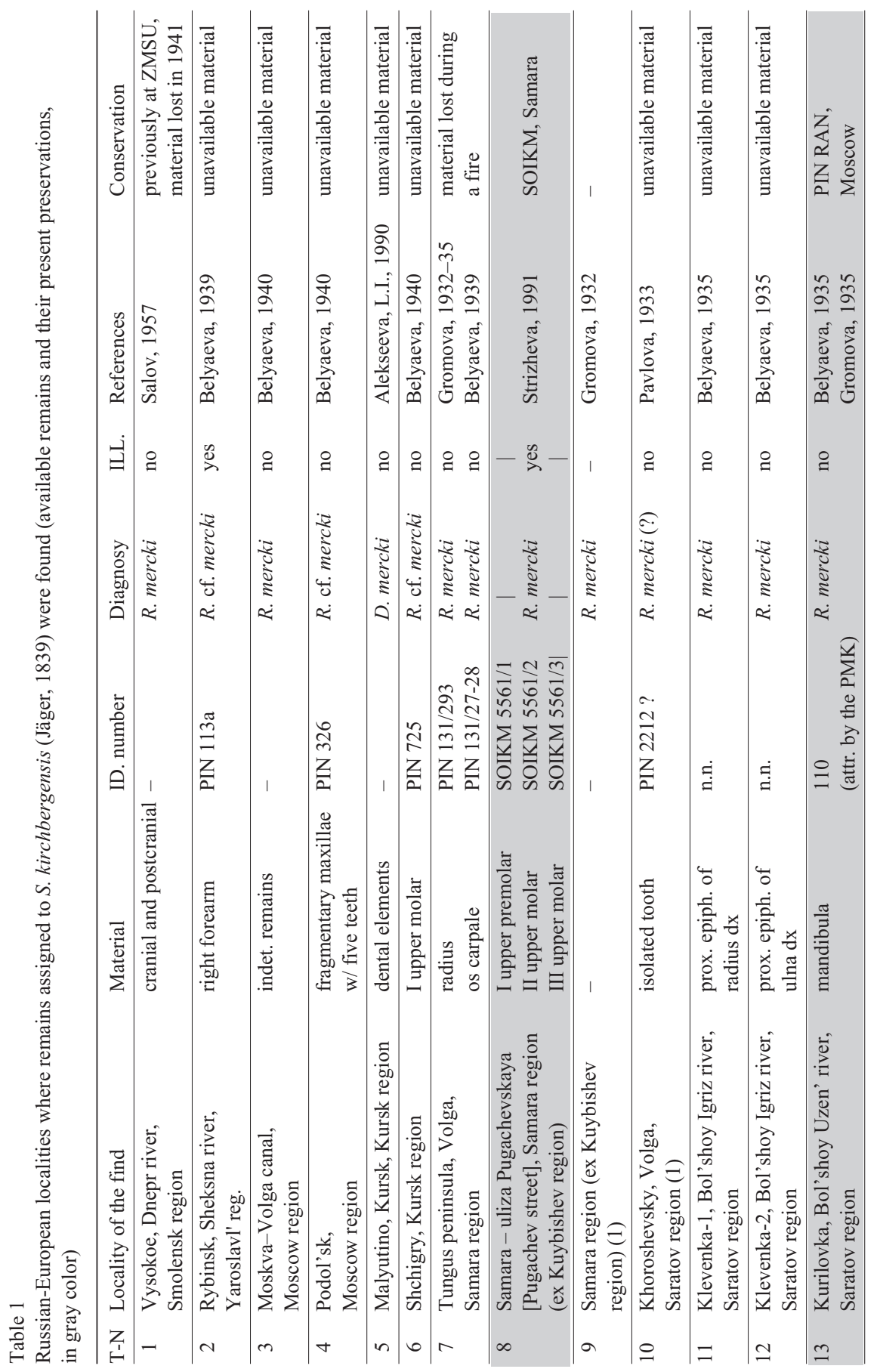


Stephanorhinus kirchbergensis (Mammalia, Rhinocerotidae) from European Russia 171
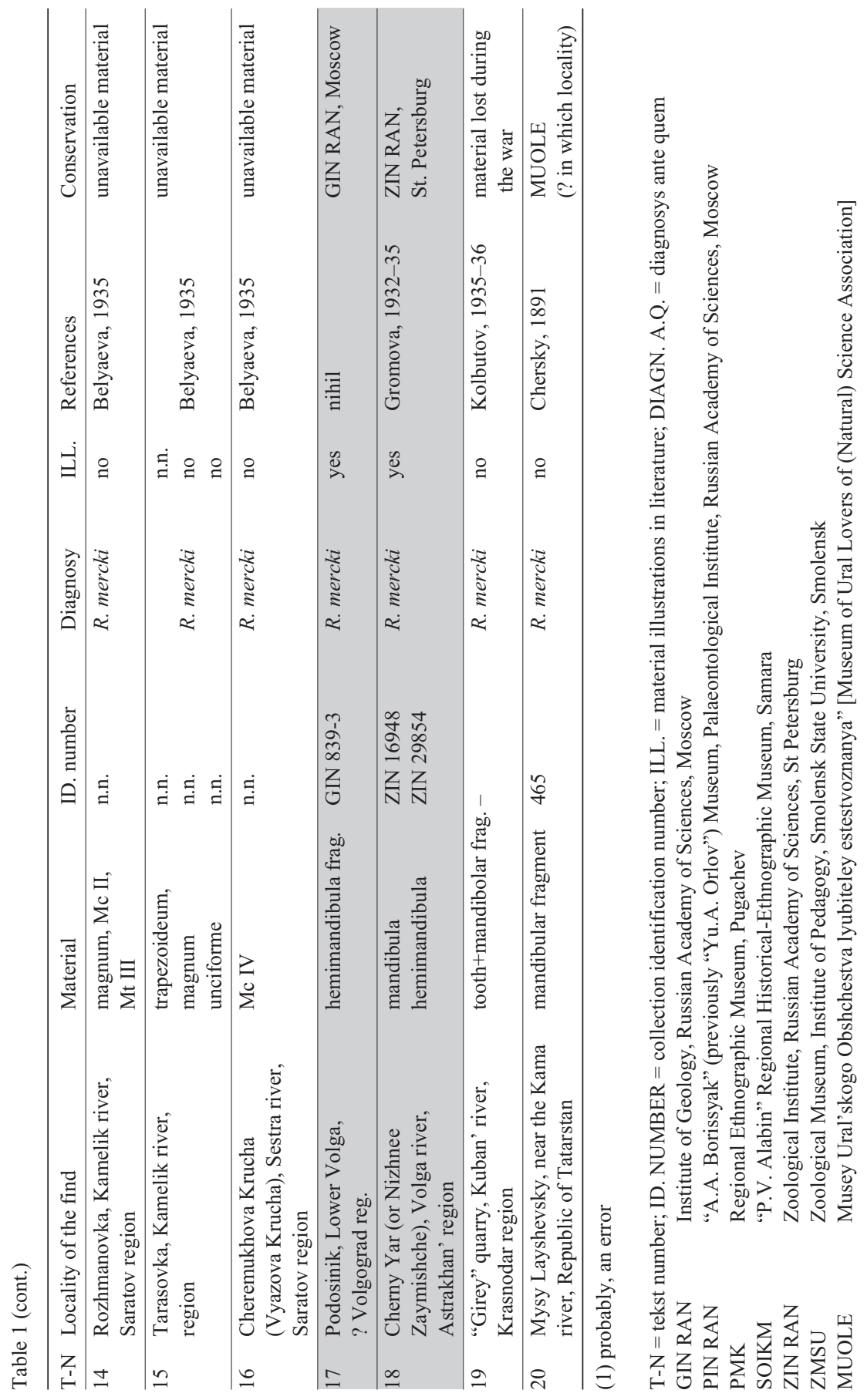

Central European Geology 57, 2014 


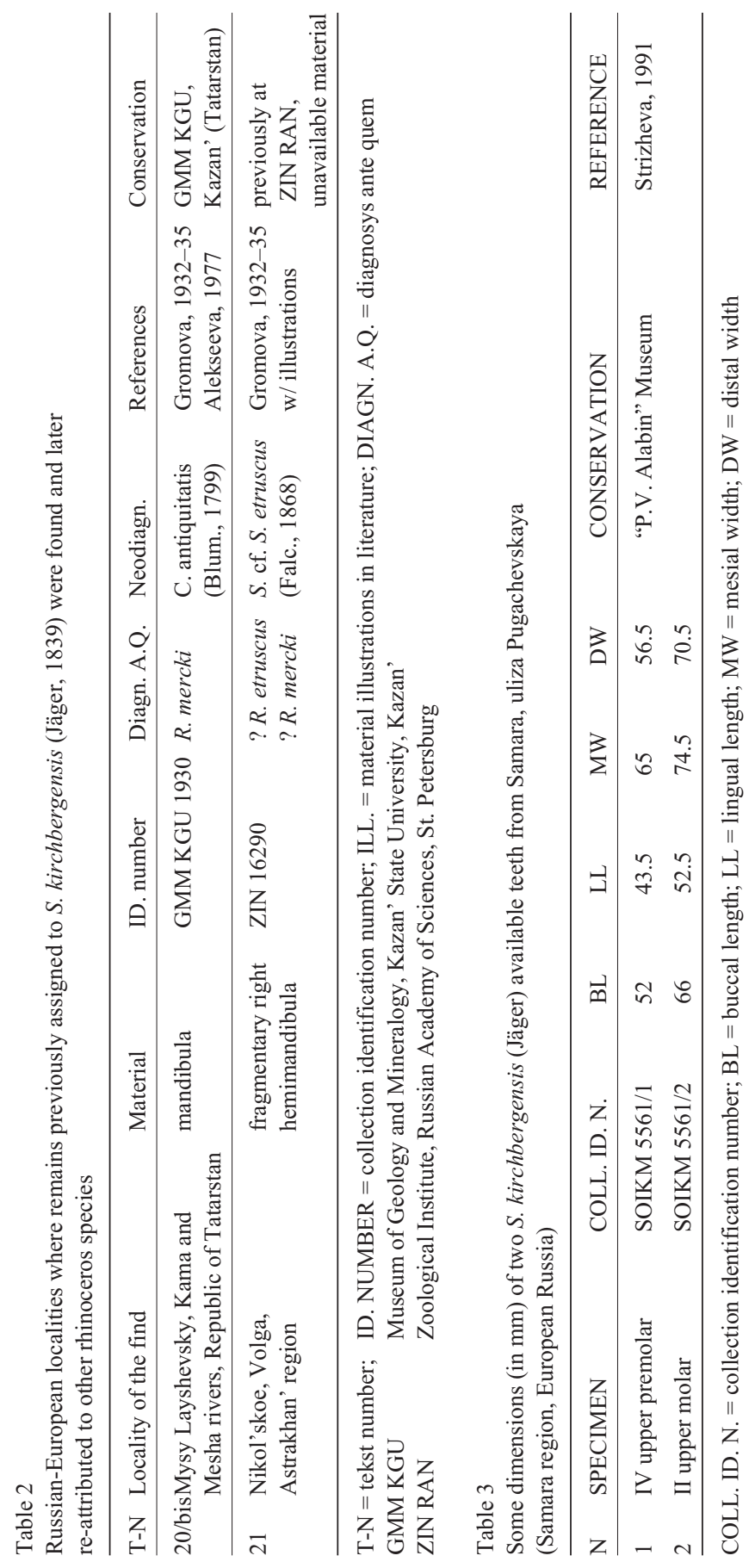


Stephanorhinus kirchbergensis (Mammalia, Rhinocerotidae) from European Russia 173

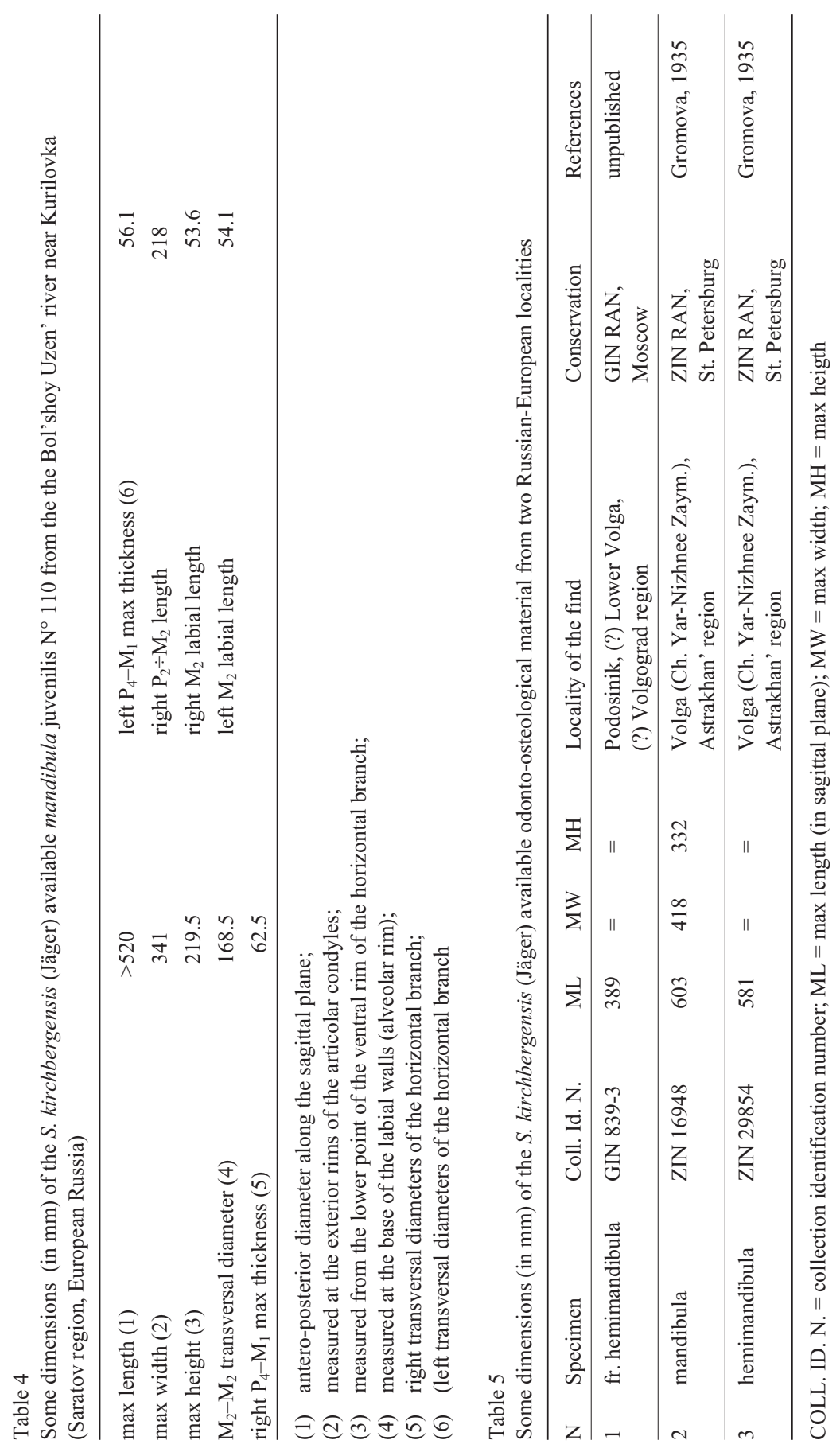




\section{Vysokoe}

Locality: at the river, at a depth of about $11 \mathrm{~m}$, along the right bank of the Dnepr near Vysokoe, about $15 \mathrm{~km}$ southeast of Smolensk (Smolensk Region).

Year of the find: 1926.

Approximate geographic co-ordinates: $54^{\circ} 42^{\prime} \mathrm{N}-32^{\circ} 15^{\prime} \mathrm{E}$.

References: Salov 1957; Gromova 1965.

Illustrations of the material: none.

Material: a skull [n.n.], two teeth [n.n.], a custula [n.n.], a scapula fragment [n.n.], and some other no better specified postcranial remains.

Preservation: at present, the material is unavailable. Previously housed at the Zoological Museum (Institute of Pedagogy) of the Smolensk State University [ZMSU], it was lost during the Nazi occupation in 1941 (Salov 1957:320-321; Gromova 1965:56).

Chronostratigraphy: unknown.

Previous attribution by Salov: Rhinoceros mercki Jaeger, 1839 (recte S. kirchbergensis).

Present attribution: impossible (material unavailable).

Accompanying fauna (biostratigraphy in the same level): none.

\section{Rybinsk}

Locality: at the depth of about $8 \mathrm{~m}$, in clayey sands in moraine deposits along the right bank of the Sheksna River, near the "Trudovik" brick kiln, about $12 \mathrm{~km}$ from Rybinsk (Yaroslavl' Region).

Year of the find: 1934.

Approximate geographic co-ordinates: $58^{\circ} 05^{\prime} \mathrm{N}-38^{\circ} 50^{\prime} \mathrm{E}$.

Reference: Belyaeva 1939a.

Illustrations of the material: seven plates and a sketch in Belyaeva (1939a).

Material: a right forearm [PIN 113a] (radius, ulna, scaphoideum, lunatum, trapezoideum, magnum, hamatum, os metacarpale II, os metacarpale III, os metacarpale IV, nine phalanges, and three ossa sesamoidea). The forearm was recovered in anatomical connection.

Preservation: at present, the material (recovered by G. Lesovik) is untraceable. Until 1939, the remains were preserved in the collections of the Rybinsk Ethnographic Museum; then, they were transferred to the PIN in Moscow. In any case, the scapula was definitely been lost years ago (Belyaeva 1939a:69).

Chronostratigraphy: Mindel-Riss (according to Belyaeva); later, V.A. Novsky (Gromov 1948:449) proposed a Riss-Würm age.

Previous attribution by Belyaeva: Rhinoceros cf. mercki Jäger 1839 (recte $S$. cf. S. kirchbergensis).

Present attribution: impossible (material not available).

Accompanying fauna (biostratigraphy in the same level): none. 


\subsection{Note}

On the basis of the III metacarpal morphology (vide plate V in Belyaeva 1939; Fig. 4 in this paper), the remains must dubiously be assigned to S. kirchbergensis. In fact - as a general rule $-S$. kirchbergensis III metacarpals are more elongate and massive, with a flatter diaphysis.

\section{Moscow-Volga canal}

Locality: close to the fourth lock of the Moscow-Volga canal, about $70 \mathrm{~km}$ north of the center of Moscow (Dmitrov District, Moscow Region).

Year of the find: unknown.

Approximate geographic co-ordinates: $56^{\circ} 25^{\prime} \mathrm{N}-37^{\circ} 30^{\prime} \mathrm{E}$.

References: Gromov 1939; Belyaeva 1940; Gromova 1965; Alekseeva 1977.

Illustrations of the material: plate XII (Figs 1-2) in Alekseeva (1977).

Material: according to Gromov (1939) and Belyaeva (1940:82), "nizhnyaya chelyust" " [a mandibula] [n.n.], whereas according to Gromova (1965:56), "pars cranii et maxillae, dentes" [n.n.]. According to Alekseeva (1977), the remains consist of the right branch of the mandible GIN b/n.n. (Fig. 5 in this paper).

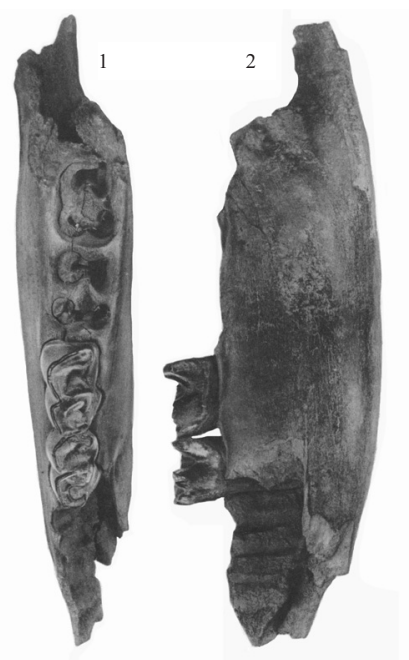

Fig. 5

Stephanorhinus kirchbergensis (Jäger, 1839); Moscow-Volga Canal (close to the fourth lock), about $70 \mathrm{~km}$ north of the center of Moscow (Dmitrov District, Moscow Region, European Russia); right branch of a mandible [GIN b/n.n.], occlusal (Fig. 1) and lateral (Fig. 2) views [after Alekseeva (1977), Pl. XII]

Preservation: at present, the material is untraceable.

Chronostratigraphy: Mindel-Riss, as suggested by the authors (Gromov 1939; Belyaeva 1940; Gromova 1965).

Previous attribution by Gromov: Rhinoceros mercki Jäger, 1839 (recte S. kirchbergensis).

Present attribution: impossible (material unavailable).

Accompanying fauna (biostratigraphy in the same level): none. 


\section{Podol'sk}

Locality: in gravel, at the depth of about $4 \mathrm{~m}$, in a clay quarry near Podol'sk, about $40 \mathrm{~km}$ south of the center of Moscow (Moscow Region).

Year of the find: spring of 1939.

Approximate geographic co-ordinates: $55^{\circ} 30^{\prime} \mathrm{N}-37^{\circ} 30^{\prime} \mathrm{E}$.

Reference: Belyaeva 1940.

Illustrations of the material: none.

Material: a maxilla fragment with five teeth [PIN 326].

Preservation: at present, the material is untraceable. Previously, it was in the collections of the PIN in Moscow, considering that in an old card-index of this Institution, under "Rhinoceros mercki (?)", I found one inscribed with "PIN 326 maxilla fragment found near Podol'sk".

Chronostratigraphy: Belyaeva (1940) referred the remains to the Russian Middle Pleistocene.

Previous Belyaeva attribution: Rhinoceros cf. mercki Jaeger, 1839 (recte $S$. cf. S. kirchbergensis).

Present attribution: impossible (material not available).

Accompanying fauna (biostratigraphy in the same level): a fragment of pelvis of Elephas sp. was also recovered, but it is not clearly indicated whether it was discovered in the same level where the S. kirchbergensis remains were found.

\section{Malyutino}

Locality: near Malyutino, about $30 \mathrm{~km}$ west of Kursk (Kursk Region).

Year of the find: unknown.

Approximate geographic co-ordinates: $51^{\circ} 40^{\prime} \mathrm{N}-35^{\circ} 55^{\prime} \mathrm{E}$.

Reference: Alekseeva L.I. 1990.

Illustrations of the material: none.

Material: some no better specified odontological remains.

Preservation: at present, the material is not traceable.

\subsection{Note}

Alekseeva (1990:25 and 65) briefly cited a discovery of "teeth attributed to Dicerorhinus mercki (Jaeger) found together with other faunal remains referred to Bison priscus Boj". No further information is available. This represents the only reference to this find in literature.

Chronostratigraphy: not available.

Previous Alekseeva attribution: Dicerorhinus mercki (Jaeger, 1839) (recte S. kirchbergensis).

Present attribution: impossible (material not available). 
Accompanying fauna (biostratigraphy in the same level): it is not clearly testified whether the remains referred to Bison priscus Bojanus 1827 were found in the same level.

\section{Shchigry}

Locality: near the village of Shchigry, about $55 \mathrm{~km}$ northeast of Kursk (Kursk Region).

Year of the find: 1938.

Approximate geographic co-ordinates: $51^{\circ} 50^{\prime} \mathrm{N}-36^{\circ} 50^{\prime} \mathrm{E}$.

Reference: Belyaeva 1940.

Illustrations of the material: none.

Material: an isolated first upper molar [PIN 725].

Preservation: at present, the material is untraceable. Previously, it was in the collections of the PIN in Moscow, considering that in an old card-index of this Institution, under "Rhinoceros mercki (?)", I found a reference to "PIN 725 tooth found near Shchigry".

\subsection{Note}

Belyaeva (1940:82) briefly mentioned "verkhnechelystny zub nosoroga ne tipa tichorhinus, vozmozhno Merka ?..." [literally, "an upper tooth of non-tichorhinus (recte C. antiquitatis) type, possibly Merck ? (= Rhinoceros mercki Jaeger ?", recte $S$. kirchbergensis Jäger ?)"] collected in 1938 with some other fossil skeletal remains (a tooth fragment of a juvenile Elephas sp. and an incisor of Equus sp.).

Chronostratigraphy: Belyaeva (1940) referred the remains to the Russian Middle Pleistocene.

Previous Belyaeva attribution: "Rhinoceros mercki Jaeger ?" (recte S. kirchbergensis ?).

Present attribution: impossible (material unavailable).

Accompanying fauna (biostratigraphy in the same level): it is not clearly testified whether the remains of S. kirchbergensis and those of Elephas sp. and Equus sp. came from the same level.

\section{Tungus - Peninsula of}

Locality: clayey land strip on the left bank of the Volga, about $11 \mathrm{~km}$ southwest of Khryashchevka and about $2 \mathrm{~km}$ southwest of the mouth of the Bol'shoy Cheremshan River (Tungus Peninsula, Samara Region). The Tungus Peninsula is situated between the towns of Sengiley and Novodevich'e, on the left bank of the Volga. 
Year of the find: 1935.

Approximate geographic co-ordinates: $53^{\circ} 30^{\prime} \mathrm{N}-49^{\circ} 05^{\prime} \mathrm{E}$.

References: Gromova 1932, 1935; Belyaeva 1939b.

Illustrations of the material: none.

Material: two upper teeth fragments [n.n.], a radius [PIN 131/293], and an os carpale [PIN 131/27-28].

\subsection{Note 1}

According to Belyaeva (1939b:86), only the two upper teeth fragments were discovered. Belyaeva ascribed the same to "Rhinoceros mercki" (recte S. kirchbergensis) considering them "different from the teeth of Rhinoceros tichorhinus (recte C. antiquitatis) and much alike to those of Rhinoceros mercki" [in Belyaeva (1939b:87): "Eti zuby po svoemu stroeniyu rezko otlichayutsya ot zubov Rh. tichorhinus i imeyut bol'shoe shodstvo s zubamy Rh. mercki"].

Preservation: the material is not available. The entire fossil collection was completely lost during a fire. The contents of this very collection is known only by the writings of P.A. Osokov.

Chronostratigraphy: Mindel-Riss or Riss-Würm (Belyaeva 1939b).

Previous Gromova attribution: Rhinoceros mercki Jaeger, 1839 (recte S. kirchbergensis).

Present attribution: impossible (material not available).

Accompanying fauna (biostratigraphy in the same level): unknown.

\subsection{Note 2}

Excavations begun in 1912 (by K.M. Kuz'minsky) were resumed in 1926, and carried on until 1936, showing a rich layer (1106 remains, about thirty species altogether) with presence of Coelodonta antiquitatis (Blumenbach 1799), Equus hydruntinus Regalia 1904, Megaloceros giganteus (Blum. 1803), Cervus elaphus L. 1758, Camelus knoblochi Nehring 1884 (= Camelus knoblochi Poljakov 1881), Bison priscus Bojanus 1827, Saiga tatarica L. 1758 , and many others together with a calcaneum and two custulae assigned to Homo sapiens cf. H. s. neanderthalensis Schwalbe (recte Homo cf. $H$. neanderthalensis King 1864). The faunal complex covers both Russian Middle and Late Pleistocene.

In this area, S. kirchbergensis is included in the so-called "Khazarskaya Fauna" [Khazar Fauna] or "Khazarsky Terio-kompleks" [Khazar Theriocomplex]. On the Khazar Fauna, see also Cheremukhova Krucha [16] and Cherny Yar (or Nizhnee Zaymishche) [18]. 


\section{Samara - City of}

Locality: Samara (ex Kuybishev), uliza Pugachevskaya [Pugachev street] (Samara region).

Year of the find: 1932.

Approximate geographic co-ordinates: $53^{\circ} \mathrm{N}-50^{\circ} \mathrm{E}$.

Reference: Strizheva 1991.

Illustrations of the material: none.

Material: an isolated fourth upper premolar [SOIKM 5561/1], an isolated second upper molar [SOIKM 5561/2], and a labial crown fragment of a third upper molar [SOIKM 5561/3].

\subsection{Note}

The remains were found in addition to five $C$. antiquitatis teeth during works under the uliza Pugachevskaya [Pugachev street]. Stratigraphic data are unavailable.

Preservation: "P.V. Alabin" Historical-Ethnographic Regional Museum, pr. Lenina 142, 443041 Samara.

Preservation status: damaged remains.

Chronostratigraphy: according to Strizheva (1991), Russian Middle Pleistocene. Previous Strizheva attribution: Dicerorhinus kirchbergensis (Jäger 1839) (recte S. kirchbergensis).

Present attribution: confirmed, S. kirchbergensis.

Accompanying fauna: dubiously $C$. antiquitatis, but the precise level in which the five teeth belonging to this species were collected is unknown.

\section{Samara - Region of}

\subsection{Note}

Brandt (1877:9) and Gromova (1935:96, par. 4) generically reported on remains of Rhinoceros mercki Jaeger (recte S. kirchbergensis) found in the Samara region (ex Kuybishev region) by Goncharov without any indication of locality. According to Brandt (1877), the material was in the collections of the "G.V. Plekhanov" Gorny Institut ["G.V. Plekhanov" Institute of Mines] in St. Petersburg. Gromova (1935:96, par. 4) also wrote that she was unable to trace the remains in the 1930s. Further information is unavailable.

In terms of facts, there is no concrete relation to this report, as well as for the discoveries on Khoroshevsky Island [10]. 


\section{Khoroshevsky - Island of (also Khvalynsk)}

In toponymy, Khoroshevsky and Khvalynsk represent two different localities. In literature, they must be considered as synonyms indicating the same paleontological site.

\subsection{Note}

In 1914 , on a bank - submerged by the Volga - of Khoroshevsky Island $\left(52^{\circ}\right.$ $15^{\prime} \mathrm{N}-48^{\circ} 10^{\prime} \mathrm{E}$ ) in front of the village of Alekseevka (about $23 \mathrm{~km}$ south of Khvalynsk and about $50 \mathrm{~km}$ northeast of Volzhsk, Khvalynsk district, Saratov region), a fossiliferous deposit was discovered. It yielded an extremely rich collection of Russian Middle and Late Pleistocene vertebrate remains (about 28 taxa, included a skull fragment showing some neanderthaloid characters). No stratigraphic data are available. Initially the fossil material was preserved at the Khvalinsk Ethnographic Museum. Later, it was transferred to the PIN in Moscow to perform a study on it.

According to some authors (Gromova 1935; Alekseeva, L.I. 1977, inter alios), Pavlova (1933) would refer to a "find of remains of Rhinoceros mercki Jaeger" (recte S. kirchbergensis). Moreover, in an old PIN card-index, under "Rhinoceros mercki (?)" (sic), I found one inscribed "PIN 2212 tooth possibly found at Khvalynsk, previously preserved in the Khvalinsk Ethnographic Museum collections, later transferred to the PIN".

After an attentive analysis of the Pavlova's paper, I did not find any reference to discoveries of $R$. mercki. On the contrary, only R. tichorhinus (recte C. antiquitatis) is listed. It is interesting to observe that - at that time - Gromova (1932:71-72) was perfectly aware of the discovery, so much so as to consider the rhinoceros material belonging to $R$. tichorhinus. This obviously represents another case of misidentification (as in the case of the discovery in the Samara Region [9]). However, the PIN 2212 isolated tooth is untraceable nor any illustrations of it are available.

\section{Klevenka-1}

Locality: on the steep left bank of the Bol'shoy Igriz River, about $1 \mathrm{~km}$ north of Klevenka (Ivanteevka District, Saratov Region).

Year of the find: between 1925 and 1930.

Approximate geographic co-ordinates: $52^{\circ} 10^{\prime} \mathrm{N}-49^{\circ} 05^{\prime} \mathrm{E}$.

Reference: Belyaeva 1935.

Illustrations of the material: none.

Material: a proximal epiphysis of radius dx [n.n.].

Preservation: at present, the material is not traceable. According to Belyaeva (1935:303), it was previously preserved at the Pugachev Ethnographic Museum 
$[\mathrm{PMK}]$ in Pugachev (Saratov region). Later, it was probably transferred by Belyaeva to the PIN in Moscow.

Chronostratigraphy: on the basis of the geologic data provided by Gromov (1933), Belyaeva (1935:306) hypothesized a Mindel or a Mindel-Riss age.

Previous Belyaeva attribution: Rhinoceros mercki Jaeger, 1839 (recte S. kirchbergensis).

Present attribution: impossible (material not available).

Accompanying fauna (biostratigraphy in the same level): Bison priscus, Mammuthus sp.

\subsection{Note}

Belyaeva (1935) briefly described the steep left bank of the Bol'shoy Igriz where fossil skeletal remains belonging to Rhinoceros mercki (recte S. kirchbergensis), Bison priscus, Mammuthus sp. (Mindel-Riss, for the three species), Ursus (Spelaearctos) spelaeus rossicus Borisiak 1930 (recte Ursus spelaeus rossicus Borisiak 1930) (Riss II-Riss-Würm), C. antiquitatis and Mammuthus sp. (Riss-Würm, for the last two species) came to light.

The fossil material was recovered between 1925 and 1930 by K.I. Zhuravlev. Named Klevenka-1, the site is situated very near Klevenka-2 [12].

\section{Klevenka-2}

Locality: on the steep right bank of the Bol'shoy Igriz River, about $2.5 \mathrm{~km}$ north of Klevenka (Ivanteevka District, Saratov Region).

Year of the find: between 1925 and 1930.

Approximate geographic co-ordinates: $52^{\circ} 10^{\prime} \mathrm{N}-49^{\circ} 05^{\prime} \mathrm{E}$.

Reference: Belyaeva 1935.

Illustrations of the material: none.

Material: a proximal epiphysis of ulna dx [n.n.].

Preservation: at present, the material is untraceable. According to Belyaeva (1935:303), it was previously preserved at the Pugachev Ethnographic Museum $[\mathrm{PMK}]$ in Pugachev (Saratov region). Later, it was probably transferred by Belyaeva to the PIN in Moscow.

\subsection{Note}

According to Belyaeva (1935:304), the remains represent the sole fossil found (by K.I. Zhuravlev between 1925 and 1930) in this site. Named Klevenka-2, it is situated very near Klevenka-1 [11]. 
Chronostratigraphy: on the basis of the geologic data provided by Gromov (1933), Belyaeva (1935:306) hypothesized a Mindel or a Mindel-Riss age.

Previous Belyaeva attribution: Rhinoceros mercki Jaeger, 1839 (recte S. kirchbergensis [Jäger, 1839]).

Present attribution: impossible (material unavailable).

\section{Kurilovka}

Locality: on the steep right bank of the Bol'shoy Uzen' River, about 5 km northeast of Kurilovka (Novouzensk District, Saratov Region).

Year of the find: 1929.

Approximate geographic co-ordinates: $50^{\circ} 40^{\prime} \mathrm{N}-48^{\circ} 05^{\prime} \mathrm{E}$.

References: Belyaeva 1935; Gromova 1935.

Illustrations of the material: none.

Material: a juvenile mandible [ $\mathrm{N}^{\circ} 110$; identification number ab origine attributed by the Pugachev Ethographic Museum] (Fig. 6 in this paper).

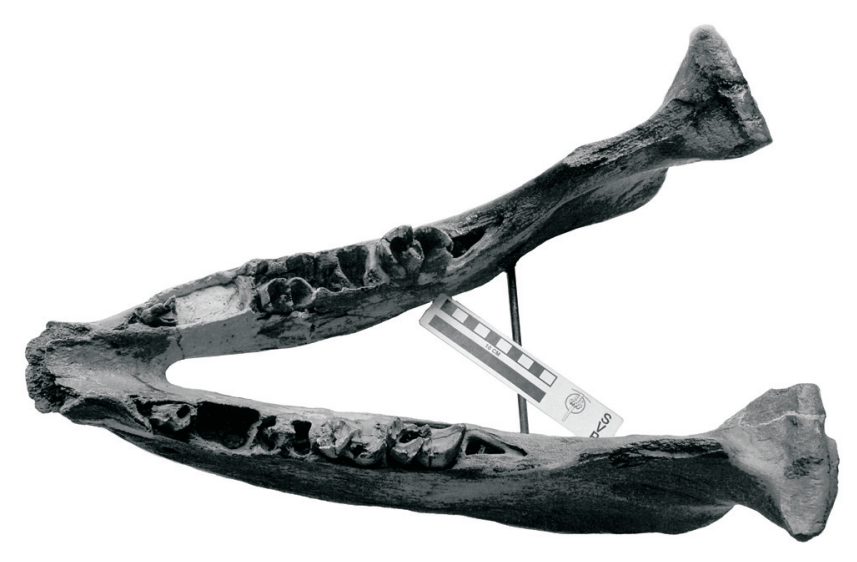

Fig. 6

Stephanorhinus kirchbergensis (Jäger, 1839); right bank of the Bol'shoy Uzen' River, about 5 km northwest of Kurilovka (Novouzensk District, Saratov Region, European Russia); juvenile mandible [PMK 110], occlusal view

Preservation: at present, "YU.A. Orlov" (at present, "A.A. Borissyak") PIN RAN Museum (Profsoyuznaya 123, 117997 Moscow). Initially it was preserved at the Pugachev Ethnographic Museum [PMK] in Pugachev (Saratov Region). Later, the mandible was given to Gromova to restore it (Belyaeva 1935:303, footnote 1; Gromova 1935:99). In future, the mandible will probably be returned to the Pugachev Ethographic Museum (uliza Toporkova 25, 413720 Pugachev).

Preservation status: damaged remains. 


\subsection{Note}

On the basis of the Pugachev Ethnographic Museum inventorial book, the mandible is the only remain found (by K.I. Zhuravlev) in this site and it would have been in the Pugachev Museum collections. The mandible had been officially considered lost for many years. I found it at the PIN RAN Museum in Moscow.

Chronostratigraphy: on the basis of the geologic data provided by Gromov (1933), Belyaeva (1935:306) hypothesized a Mindel or a Mindel-Riss age.

Previous Belyaeva and Gromova attributions: Rhinoceros mercki Jaeger, 1839 (recte S. kirchbergensis).

Present attribution: confirmed, S. kirchbergensis.

Accompanying fauna (biostratigraphy in the same level): none.

\section{Rakhmanovka}

Locality: on the steep left bank of the Kamelik River, about $2 \mathrm{~km}$ north of Rakhmanovka, at the border between the districts of Pugachev and Perelyub (Saratov Region).

Year of the find: July of 1928.

Approximate geographic co-ordinates: $51^{\circ} 55^{\prime} \mathrm{N}-49^{\circ} 15^{\prime} \mathrm{E}$.

Reference: Belyaeva 1935.

Illustrations of the material: none.

Material: an os magnum dx [n.n.], an os metatarsale II dx [n.n.], an os metatarsale III dx [n.n.], and a phalanx III3 [n.n.].

Preservation: at present, the material is not traceable. According to literature, it was formerly preserved at the Pugachev Ethnographic Museum [PMK] in Pugachev (Saratov Region). Later, it was probably transferred by Belyaeva to the PIN in Moscow.

\subsection{Note}

The material was recovered by K.I. Zhuravlev together with remains assigned to Bison priscus longicornis Gromova 1935 and Megaloceros giganteus (Blum 1803).

Chronostratigraphy: Belyaeva (1935:306) - on the basis of the geologic data provided by Gromov (1933) and considering the accompanying presence of $B$. priscus longicornis and M. giganteus - suggested a Mindel or a Mindel-Riss age. Previous Belyaeva attribution: Rhinoceros mercki Jaeger, 1839 (recte S. kirchbergensis).

Present attribution: impossible (material not available). 
Accompanying fauna (biostratigraphy in the same level): it is not clearly testified whether the remains of S. kirchbergensis and those of B. priscus longicornis and M. giganteus came from the same level.

\section{Tarasovka}

Locality: on the right bank of the Kamelik River, about $3 \mathrm{~km}$ north of Tarasovka (Pugachev District, Saratov Region).

Year of the find: unknown.

Approximate geographic co-ordinates: $52^{\circ} 05^{\prime} \mathrm{N}-49^{\circ} 20^{\prime} \mathrm{E}$.

Reference: Belyaeva 1935.

Illustrations of the material: none.

Material: an os magnum sx [n.n.], an os trapezoideum sx [n.n.], and an os unciforme sx [n.n.].

Preservation: at present, the material is untraceable. According to literature, it was formerly preserved at the Pugachev Ethnographic Museum [PMK] in Pugachev (Saratov Region). Later, it was probably transferred by Belyaeva to the PIN in Moscow.

\subsection{Note}

The material - found together with remains of Mammuthus sp. and Vulpes sp. and recovered by K.I. Zhuravlev - belongs to the same individual.

Chronostratigraphy: on the basis of the geologic data provided by Gromov (1933), Belyaeva (1935:306) hypothesized a Mindel or a Mindel-Riss age.

Previous Belyaeva attribution: Rhinoceros mercki Jaeger, 1839 (recte S. kirchbergensis).

Present attribution: impossible (material not available).

Accompanying fauna: it is not clearly indicated whether the remains of S. kirchbergensis and those of Mammuthus sp. and Vulpes sp. were found in the same level.

\section{Cheremukhova Krucha}

Locality: on the right bank of the Sestra River, at the village of Cheremukhova Krucha (Vyazova Krucha) (Perelyub District, Saratov Region).

Year of the find: between 1925 and 1930.

Approximate geographic co-ordinates: $52^{\circ} 05^{\prime} \mathrm{N}-49^{\circ} 30^{\prime} \mathrm{E}$.

Reference: Belyaeva 1935.

Illustrations of the material: none.

Material: an os metacarpale IV sx [n.n.]. 


\subsection{Note}

The material was found by K.I. Zhuravlev together with remains of Elasmotherium sibiricum Fischer v. Waldheim 1808. They are included here in the so-called "Khazarskaya Fauna" [Khazar Fauna] or "Khazarsky Teriokompleks" [Khazar Therio-complex]. On the Khazar Fauna, see also the Tungus Peninsula [7] and Cherny Yar (or Nizhnee Zaymishche) [18].

Preservation: at present, the material is not traceable. According to literature it was formerly preserved at the Pugachev Ethnographic Museum [PMK] in Pugachev (Saratov Region). Later, it was probably transferred by Belyaeva to the PIN in Moscow.

Chronostratigraphy: on the basis of the geologic data provided by Gromov (1933), Belyaeva (1935:306) hypothesized a Mindel or a Mindel-Riss age.

Previous Belyaeva attribution: Rhinoceros mercki Jaeger, 1839 (recte S. kirchbergensis).

Present attribution: impossible (material not available).

Accompanying fauna (biostratigraphy in the same level): E. sibiricum.

\section{Podosinik}

Locality: Podosinik village, along the Volga (? Volgograd Region). No other information is available (locality not found in atlases, e.g. the atlas of the Russian Federal Geographical and Cartographic Survey, Moscow 1998) (Volgograd Region $=$ ex Stalingrad Region).

Year of the find: 1937.

Approximate geographic co-ordinates: non determinable.

References: unpublished material.

Illustrations of the material: none.

Material: a fragmentary hemimandible [GIN 839-3].

Preservation: Laboratory of the Pleistocene Stratigraphy, Geological Institute [GIN RAN], Russian Academy of Sciences, Pyzhevsky per. 7, 109017 Moscow. Preservation status: damaged remains.

\subsection{Note}

Fossil remains not reported in literature. Outwardly, on the horizontal branch, a singular hand-written inscription: "pravaya vetv' nizhney chelyusti (kollekzya 839-3) naydena 9 Maya 1937 goda krestyaninom (Aleksandrom Krotkovym) v 25 shagakh na yug ot derevni Podosinik (reka Volga) - na doroge" [literally, "right branch of a lower maxilla (collection 839-3), found 
on May 9, 1937 by a farmer (Aleksandr Krotkov) at 25 steps south of Podosinik village (Volga River) - on the way" (obviously, on the Aleksandr Krotkov way)].

No further information is available, such as the region where the village of Podosinik is situated. At present, the official Russian atlases do not report toponyms as "Podosinik". We can make three suppositions: 1) throughout the years, this locality has changed its name (this is a very common situation, especially after Perestroika); 2) Podosinik village is a very small agglomeration along the Volga not reported on the maps; 3 ) a transcription error.

At present we may postulate that Podosinik is (or was) probably situated along the Middle-Lower Volga.

Chronostratigraphy: unknown.

Previous attribution (by ?): Rhinoceros mercki Jaeger, 1839 (recte S. kirchbergensis).

Present attribution: confirmed, S. kirchbergensis.

Accompanying fauna (biostratigraphy in the same level): none.

\section{Cherny Yar (or Nizhnee Zaymishche)}

In toponymy, Cherny Yar and Nizhnee Zaymishche represent two different localities. In literature, both localities may indiscriminately be cited. However, they must be considered as synonyms indicating the same paleontological site.

Geographic note: "Cherny Yar" ["steep black bank"] is a very common toponym of many villages in Russia. According to the official atlases, throughout Russian Federation territory there exist not less than 12 localities named "Cherny Yar". Locality: on the right bank of the lower course of the Volga, between the villages of Cherny Yar and Nizhnee Zaymishche (Astrakhan' Region).

Year of the find: 1929.

Approximate geographic co-ordinates: $48^{\circ} 05^{\prime} \mathrm{N}-46^{\circ} 10^{\prime} \mathrm{E}$.

Reference: Gromova 1935

Illustrations of the material: in Gromova 1935 (Pl. I-Figs 1, 2; Pl. II-Figs 5, 6; Pl. III-Figs 8, 9).

Material: a full mandible [ZIN 16948] and a right hemimandible [ZIN 29854].

18.1. Note 1: on the identification numbers of the remains

In Gromova (1935:98-101), the ZIN 16948 mandible is correctly reported, whereas in literature it is erroneously cited as GIN 16948. The ZIN 29854 hemimandible is reported by Gromova (1935:99-101), without identification number. 


\subsection{Note 2: on the ZIN 16948 mandible}

Gromova (1935:98 and followings - Pl. I-Fig. 1; Pl. II-Fig. 5; Pl. III-Fig. 8) shortly referred to a full mandible (ZIN 16948) - by the same author attributed to "Rhinoceros mercki Jaeger, - coming from the lower course of the Volga near Cherny Yar", without further information.

In the old ZIN collection card ledgers, the mandible is indicated by the number "399-1932" as well as in a ZIN card-index under "Rhinoceros merckii Jaeg.". Both sources also give the date of the discovery - "30.IX.1929" - and that the specimen "formerly preserved at the Astrakhan' Ethnographic Museum, was transferred to the ZIN by P.A. Pravoslavlev".

\subsection{Note 3: on the ZIN 29854 hemimandible}

In literature, only Gromova (1935:98 and following - Pl. I-Fig. 2; Pl. II-Fig. 6; Pl. III-Fig. 9) briefly reported on a right hemimandible - without identification number - ascribed by the same author to Rhinoceros mercki Jaeger "coming from the lower course of the Volga near Cherny Yar and preserved at the Geologichesky Kabinet Leningradskovo Universiteta [Geologic Laboratory of the Leningrad State University]".

In the old ZIN collection card ledgers I found a reference to a hemimandible (ZIN 29854; $\mathrm{N}^{\circ}$ 179-1971) assigned to Rhinoceros mercki and unearthed "on 2.X.1929 along the lower course of the Volga near Cherny Yar". As far as facts are concerned, this reference is concrete proof within the ZIN RAN Museum collections. When comparing the ZIN 29854 remains with the Gromova (1935) illustrations (see above), we may easily conclude that the ZIN 29854 hemimandible is the same reported by Gromova.

Preservation: formerly, both remains [ZIN 16948 and ZIN 29854] were in the Astrakhan' Ethnographic Museum collections. At present, they are at the ZIN RAN (Laboratory of Theriology, History of the Fauna Branch, Universitetskaya Naberezhnaya 1, 199034 St. Petersburg).

Preservation status: damaged remains.

Chronostratigraphy: Mindel-Riss (according to Gromova 1935).

Previous Gromova attribution: Rhinoceros mercki (recte S. kirchbergensis) in both the cases.

Present attribution: confirmed, S. kirchbergensis in both the cases.

Accompanying fauna (biostratigraphy in the same level): unknown.

18.4. Note 4: on the paleontological site

It was very rich in fauna. From 1929 until 1931, remains belonging to 27 mammalian species - Homo sp. included (an ulna and a tibia) - were col- 
lected. Svitoch and Yanina (1997) provided new data on the basis of which fourteen different levels (from $\mathrm{Q}_{\mathrm{IV}}$ to $\mathrm{Q}_{\mathrm{I}}^{\mathrm{b}}\left[=\mathrm{NP}_{\mathrm{IV}}\right.$ to $\left.\mathrm{NP}_{\mathrm{I}}^{\mathrm{b}}\right]$ ) are recognized in this site. The faunal complex here covers all of the Pleistocene.

$S$. kirchbergensis is included here in the so-called "Khazarskaya Fauna" [Khazar Fauna] or "Khazarsky Terio-kompleks" [Khazar Therio-complex]. On the Khazar Fauna, see also the Tungus Peninsula [7] and Cheremukhova Krucha [16].

The site is situated about $40 \mathrm{~km}$ northwest of Nikol'skoe [21].

18.5. Note 5: on a new find from Cherny Yar

Recently (2012), a Mc IV apparently very close to those belonging to $S$. kirchbergensis has been found (the remains have not yet been published).

\section{9. "Girey" Quarry}

Locality: "Girey" Quarry, on a Kuban' River terrace, near the village of Girey and the Kavkaz railway station, not far from the town of Kropotkin (Kuban' River Basin, Krasnodar Region, Northern Caucasus).

Year of the find: $1935-36$.

Approximate geographic co-ordinates: $45^{\circ} 05^{\prime} \mathrm{N}-38^{\circ} 30^{\prime} \mathrm{E}$.

References: Kolbutov 1935-36; Gromov 1948; Vereshchagin 1959.

Illustrations of the material: none.

Material: a molar on a mandibular fragment [n.n.].

Preservation: material not available. According to literature, the remains (collected by A.D. Kolbutov) would have been in the osteological collections of the Kropotkin Regional Museum.

\subsection{Note}

Gromov (1948:50-52) pro parte refers to the Kolbutov (1935-36) report. Furthermore, Gromov (1948:448-449) also briefly reports on "Rhinoceros mercki Jaeger and on its scarce presence on USSR territory" (as well as in Belyaeva [1935:306], in Alekseeva, E.V. [1980:58], inter alios). Only Vereshchagin (1959:92, footnote 1) states that "the isolated lower molar of Rhinoceros mercki (recte S. kirchbergensis) and the fossil remains assigned to Rhinoceros antiquitatis (recte C. antiquitatis), Elephas wüsti Pavlova, 1914 (recte Mammuthus trogontherii [Pohlig, 1885]), Elephas primigenius (recte Mammuthus primigenius [Blum.]), Bison priscus $\mathrm{cf}$. B. p. longicornis, Bison priscus deminutus, and Megaloceros sp. have been lost [literature original text, "byli utracheny"] during World War II. 
Chronostratigraphy: according to the authors, Mindel or Mindel-Riss age.

Previous Kolbutov (?) attribution: Rhinoceros mercki Jaeger (recte S. kirchbergensis).

Present attribution: impossible (material unavailable).

Accompanying fauna: it is not clearly testified whether the remains of S. kirchbergensis and those of $R$. antiquitatis (recte $C$. antiquitatis), E. wüsti (recte $M$. trogontherii), E. primigenius (recte M. primigenius), B. p. deminutus, B. p. cf. B. $p$ longicornis, and Megaloceros sp., were found in the same level.

\section{Mysy Layshevsky}

Locality: village of Mysy near the Kama River (Layshev District, Republic of Tatarstan).

Year of the find: 1890.

Approximate geographic co-ordinates: $55^{\circ} 45^{\prime} \mathrm{N}-51^{\circ} 30^{\prime} \mathrm{E}$.

References: Chersky 1891:607; Gromova 1935:97; Aver'yanov et al. 1992:68.

Illustrations of the material: none.

Material: a mandibular fragment [ $\left.\mathrm{N}^{\circ} 465\right]$.

Preservation: at that time, "Musey Ural'skogo Obshchestva lyubiteley estestvoznanya" [Museum of Ural Lovers of (natural) science Association], without any indication of the locality (Chersky 1891; Gromova 1935; Aver'yanov et al. 1992).

Previous Chersky attribution: Rhinoceros mercki Jaeger (recte S. kirchbergensis). Present attribution: impossible (material not found).

No further data are available.

From the following two other Russian-European localities comes material previously erroneously assigned to $S$. kirchbergensis, afterwards re-attributed to other Pleistocene rhinoceros species, respectively, C. antiquitatis and Stephanorhinus cf. S. etruscus (Falconer 1868).

\section{0/bis. Mysy Layshevsky}

Locality: on the right bank of the Kama River, between the mouths of the Kama and Mesha Rivers, near the village of Mysy Layshevsky (Layshev District, Republic of Tatarstan).

Year of the find: not indicated.

Approximate geographic co-ordinates: $55^{\circ} 45^{\prime} \mathrm{N}-51^{\circ} 30^{\prime} \mathrm{E}$.

References: Gromova 1932, 1935; Alekseeva, L.I. 1977; Aver'yanov et al. 1992:67.

Illustrations of the material: none.

Material: a mandible [GMM KGU 1930]. 
Preservation: Museum of Geology and Mineralogy, Institute of Geology and Paleontology, Kazan' State University [GMM KGU] (uliza Kremleva 18, 420007 Kazan', Republic of Tatarstan).

Preservation status: a very well-preserved specimen.

Previous authors attribution: Rhinoceros mercki Jaeger by Gromova and Dicerorhinus mercki (Jäger, 1839) by Alekseeva (in both cases, recte S. kirchbergensis). Present attribution (new diagnosis by Billia): the dental morphological characteristics shown by the teeth of the well-preserved mandible GMM KGU 1930 - erroneously referred to as $R$. mercki by Gromova $(1932,1935)$ and as Dicerorhinus mercki by Alekseeva (1977) - are peculiar of C. antiquitatis. For this reason, it must be attributed to this last taxon.

\section{Nikol'skoe}

Locality: on the right bank of the lower course of the Volga, near the village of Nikol'skoe, about $170 \mathrm{~km}$ southeast of Volgograd (ex Stalingrad) and about 200 km northwest of Astrakhan' (Astrakhan' Region, European Russia).

Year of the find: summer of 1930.

Approximate geographic co-ordinates: $47^{\circ} 50^{\prime} \mathrm{N}-46^{\circ} 15^{\prime} \mathrm{E}$.

References: Gromova 1932, 1935.

Illustrations of the material: Gromova (1932, Pl. V-Figs 1,2).

Material: a juvenile right fragmentary hemimandible [previously NGI 84, later ZIN 16290] with a third and a fourth deciduous molar $\left(D_{3}, D_{4}\right)$, a first and a second permanent molar $\left(\mathrm{M}_{1}, \mathrm{M}_{2}\right)$.

\subsection{Note 1: on the specimen}

In Gromova $(1932: 153,155,183)$, the specimen is cited as NGI 84 , while in Gromova (1935:98, 99, and 102), the same is reported as ZIN 16290 (just as later in Avakyan 1959:33). In the relatively copious literature of the 20th century the hemimandible is erroneously reported as GIN 16290 or GIN 16948. It is necessary to bear in mind that very frequently in literature the GIN 16948 inventorial number was erroneously identified with the mandible coming from Cherny Yar (or Nizhnee Zaymishche [18]).

\subsection{Note 2: on the paleontological site}

The hemimandible was recovered during work carried out - along that part of the Volga - by the Neftyany Geologo-Razvedochny Institut [NGI] [Petroleum Geologic Investigation Institute]. Together with the hemimandible, abundant fossil skeletal material ascribed to many mammalian species was collected. Later (between 1960 and 1983) other systematic excavations were 
carried out at this site, allowing recognition of six different levels in stratigraphic succession (from $\mathrm{Q}_{\mathrm{IV}}$ to $\mathrm{Q}_{\mathrm{I}}\left[=\right.$ from $\mathrm{NP}_{\mathrm{IV}}$ to $\left.\mathrm{NP}_{\mathrm{I}}\right]$ ).

The site lies about $40 \mathrm{~km}$ southeast of Cherny Yar (or Nizhnee Zaymishche [18]).

Preservation: at present, the material is untraceable. Previously preserved at the NGI (here identified as NGI 84), later it was entrusted by Gromova (Gromova 1932:69) to the ZIN in St. Petersburg. Here, in an old card-index, under "Rhinoceros merckii", I found a card concerning this hemimandible correctly identified by the ZIN 16290 identification number.

Chronostratigraphy: Mindel age, according to Gromova (1932:170).

Previous authors attribution: "Rhinoceros sp.? (Mercki Jaeg. aut etruscus Falc.)" [= Rhinoceros sp.? (S. kirchbergensis Jäg. aut S. etruscus Falc.)] (Gromova 1932:74 and 153-156), whereas later Gromova $(1935: 98-99,102)$ dubiously ascribed the hemimandible to "Mercki Jäg".

Present attribution (new diagnosis by Billia): on the basis of the morphology of the first molar $\left(\mathrm{M}_{1}\right)(\mathrm{Pl}$. V, Figs 1, 2 in Gromova 1932), the hemimandible would have to be attributed to Stephanorhinus cf. S. etruscus (Falconer, 1868) (= Rhinoceros cf. R. etruscus Falconer, 1868).

\section{Remarks}

On the basis of the fossil evidence, S. kirchbergensis - though widely spread throughout Eurasia - seems to be decidedly rare on Russian territory (just as in the rest of Eurasia). On the other hand, some authors (Gromova 1932, 1935, 1965; Belyaeva 1935, 1940; Gromov 1948; Alekseeva 1980) pointed out the scarce presence of S. kirchbergensis in Russia. Furthermore - as a general rule - all the Dicerorhinae appear to be rare in Russia.

In the present paper, often neither chrono- nor biostratigraphic data are available because of the lack of reliable data.

As to the S. kirchbergensis Russian European distribution, the Middle-Lower Volga area represents one of the few "concentrations" of the discoveries of remains ascribed to this species.

The few other S. kirchbergensis remains from Asian Russia (Western Siberia) have been described in previous papers in detail (Billia 2007; Shpansky and Billia 2012). During a study of the material housed at the Kemerovo Regional Ethnographic Museum, I verified that the KKM 70 remains - found in Novokuznetsk (ex Stalinsk) (Kemerovo Region, southeast Western Siberia) - reported by Alekseeva (1980:58) as a "Dicerorhinus kirchbergensis hemimandible" actually corresponds to an Elephas sp. hemimandible.

As to Eastern Siberia, to date the most noteworthy Russian record (quite rarely mentioned in European literature) concerns the ZIN 10718 skull from the Irkutsk region (Chersky 1874; Brandt 1877; Billia 2008b, 2010), while the northernmost 
one (because of its extraordinary latitude close to $64^{\circ} \mathrm{N}$ ) is represented by the two teeth (PIN 750/139-140) from the Vilyuy River (Sakha Republic/Yakutya) (Dubrovo 1957). So far these are the only two records from Eastern Siberia.

Some authors (Schrenck 1880:2; Freidel 1880:353-359; Woodward 1881:90) reported on "a body of a large Rhinoceros ... found [in 1877] on the bank of a small tributary to the Yana River [Verkhoyansk District, Yakutya, Northeastern Siberia] ... remarkably well-preserved ... and covered by long hair ...". Considering the "body covered by long hair", we may confidently assign these remains to C. antiquitatis.

Finally, in the Russian European museum collections, few other S. kirchbergensis specimens - even if recovered elsewhere than Russia - are also available. They come from Poland and Kazakhstan (Pusch 1836; Brandt 1877:97, Pl. III-Figs 2, 3, 4; Chersky 1891:519-520; Gromova 1935:95 and 102, Pl. I-Fig. 3, Pl. II-Fig. 7, Pl. III-Fig. 10; Khisarova 1963-Pl. II-III; vide autem in Billia 2011).

\section{Acknowledgements}

During my long stay in Russia, I had the opportunity of meeting many people who overwhelmed me with their typical Russian hospitality, attention, and availability. I am very much indebted, and particularly grateful, to all my Russian friends and colleagues for having very kindly and generously dedicated their time in supporting my work in all possible ways, for enabling my access to the rhinoceros collections, and for providing me with continuous valuable comments and useful suggestions. I am greatly indebted to all the Directors and the Staff of many Russian Institutions which I have visited and where I proved to be a very difficult and demanding guest (in order of institution): $\uparrow$ Irina A. Dubrovo, Aleksandr K. Agajanyan, Evgeny N. Mashchenko (Paleontological Institute, Russian Academy of Sciences [PIN RAN], Moscow); † Eleonora A. Vangengeym, Marina V. Sotnikova, and Vladimir I. Zhegallo (Geological Institute, Russian Academy of Sciences [GIN RAN], Moscow); Evgeny G. Mirlin and Natalya G. Noskova ("V.I. Vernadsky" Geological Museum, Russian Academy of Sciences, Moscow); Aleksandr O. Aver'yanov, Gennady F. Baryshnikov and Aleksey N. Tikhonov (Zoological Institute, Russian Academy of Sciences [ZIN RAN], St. Petersburg); Nina V. Garutt (Gorny Institut "G.V. Plekhanov" ["G.V. Plekhanov" Institute of Mines], St. Petersburg); Gennady N. Kiselev (Chair of Paleontology, Faculty of Geology, St. Petersburg State University, St. Petersburg); Galina S. Timashkova, Tat'yana Kurazheva, and Antonina A. Alenicheva ("F.N. Chernyshev" Central Museum for Scientific Research and Geological Investigation, St. Petersburg); Larisa V. Guseva ("P.V. Alabin" Historical Ethnographic Regional Museum [SOIKM], Samara); Evgeny S. Shulikov (Geo-Mineralogical Museum [GMM KGU], Kazan' State University, Kazan'); Nurya I. Suleymanova (Ethnographic Regional Museum, Pugachev); Margarita A. Erbayeva and Nadezhda V. Alekseeva (Geological Institute, Russian Academy of Sciences, Si- 
berian Branch [GIN RAN], Ulaan-Ude, Buryatya); the Staff of the Buryatyan Museum of Natural History, Ulaan-Ude (Buryatya); $\uparrow$ Aleksandr I. Rodygin, and all the Members of the Department of Paleontology and Historical Geology, Tomsk State University [TGU], Tomsk); Svetlana Konstantinovna and Alevtina Leonidovna (Scientific Library, Tomsk State University [NB TGU], Tomsk); Ol'ga M. Shaduyko (Office for the International Affairs, Tomsk State University [TGU], Tomsk).

For critical reading and commenting the original draft of the manuscript, I would like to express my heartfelt gratitude to Daniel Ziegler (Editor on Fossil Rhinoceroses, Rhino Resource Center). My stay in the Russian Federation to perform my research was partly supported by a NATO research grant.

\section{References}

Alekseeva, E.V. 1980: Mlekopitayushchie pleystozena Yugo-Vostoka Zapadnoy Sibiri (Hishchnye, Khobotnye, Kopytnye) (Pleistocene mammals from southeast Western Siberia) (in Russian). Akademya Nauk SSSR, Dal'nevostochny Nauchny Zentr Biologii (Pochv. Institut), Izd-vo "Nauka", Moskva, 187 pp.

Alekseeva, L.I. 1977: Teriofauna rannego antropogena Vostochnoy Evropy (Early anthropogene theriofauna of Eastern Europe) (in Russian). - Trudy Geologicheskogo Instituta, Akademya Nauk SSSR, Izd-vo "Nauka", 300, Moskva, pp. 1-214.

Alekseeva, L.I. 1990: Teriofauna Verkhnego Pleystozena Vostochnoy Evropy (Krupnye Mlekopitayushchie) (Late Pleistocene theriofauna of Eastern Europe [Large mammals]) (in Russian, English abstract). Akademya Nauk SSSR (Geologichesky Institut), Izd-vo "Nauka”, Moskva, 109 pp.

Avakyan, L.A. 1959: Chetvertichnye iskopaemye mlekopitayushchie Armenii (Quaternary fossil mammals of Armenia) (in Russian). - Izd-vo Akademya Nauk Armyanskoy SSR, Erevan, pp. 31-34.

Aver'yanov, A.O., G.F. Baryshnikov, V.E. Garutt, N.V. Garutt, L.N. Fomicheva 1992: Volzhskaya fauna pleystozenovykh mlekopitayushchikh v kollekzii Geologo-Mineralogicheskogo Muzeya Kazanskogo Gosudarstvennogo Universiteta (Volga fauna in the collections of the Geological-Mineralogical Museum of the Kazan' State University) (in Russian). - Izd-vo Kazanskogo Gosudarstvennogo Un-ta, Kazan', 163 pp.

Belyaeva, E.I. 1935: Nekotorye dannye o chetvertichnykh mlekopitayuscikh iz Nizhnevolzhskogo kraya po materialam muzeya g. Pugach. Zemlya (Some data on the Quaternary mammals from the area of the lower Volga based on the material housed in the Pugachev Regional Museum) (in Russian, German abstract). - In: Trudy Komissii po Izuchenyu Chetvertichnogo Perioda, IV, (2), pp. 303-308, Akademya Nauk SSSR, Izd-vo AN SSSR, Moskva - Leningrad.

Belyaeva, E.I. 1939a. Ob ostatkakh iskopaemogo nosoroga iz okrestnostey g. Rybinska (On fossil rhinoceros remains from the environs of Rybinsk). - In: Voprosy Stratigrafii Chetvertichnykh Otlozhenii i ee Paleontologicheskoe Obosnovanie (in Russian). - Byulleten’ Komissii po Izuchenyu Chetvertichnogo Perioda, 5, pp. 69-90, Izd-vo Akademya Nauk SSSR, Moskva - Leningrad.

Belyaeva, E.I. 1939b: Zametki ob ostatkakh mlekupitayushchikh poluostrova Tunguz (On the mammalian remains from the Tunguz Peninsula) (in Russian). - Byulleten’ Moskovskogo obshchestva ispytateley prirody (Otdel geologichesky), 17(6), pp. 76-79, Moskva.

Belyaeva, E.I. 1940: Novye nakhodki ostatkov nosoroga Merka na territorii SSSR (New finds of Merck's rhinoceros remains on the Soviet Union territory) (in Russian). - Priroda (Paleozoologya), 8, p. 82, Izd-vo Akademya Nauk SSSR, Moskva/Leningrad

Billia, E.M.E. 2007: First records of Stephanorhinus kirchbergensis (Jäger, 1839) (Mammalia, Rhinocerotidae) from the Kuznetsk Basin (Kemerovo region, Kuzbass area, South-East of Western Siberia). Bollettino della Società Paleontologica Italiana, 46(2-3), pp. 95-100, Modena. 
Billia, E.M.E. 2008a: Revision of the fossil material attributed to Stephanorhinus kirchbergensis (Jäger, 1839) (Mammalia, Rhinocerotidae) preserved in the museum collections of the Russian Federation. Quaternary International, 179, pp. 25-37.

Billia, E.M.E. 2008b: The skull of Stephanorhinus kirchbergensis (Jäger, 1839) (Mammalia, Rhinocerotidae) from the Irkutsk region (Southwest Eastern Siberia). - Quaternary International, 179, pp. 20-24.

Billia, E.M.E. 2010: The famous Stephanorhinus kirchbergensis (Jäger, 1839) "Irkutsk skull” (Mammalia, Rhinocerotidae) from southwest Eastern Siberia briefly compared with those from Krapina and Warsaw (Eastern Europe). - Studii și comunicări. Științele Naturii, 26(1), pp. 296-302, Muzeul Olteniei, Craiova.

Billia, E.M.E. 2011: Occurrences of Stephanorhinus kirchbergensis (Jäger, 1839) (Mammalia, Rhinocerotidae) in Eurasia. An account. - Acta Palaeontologica Romaniae, 7, pp. 17-40.

Brandt, J.F. 1877: Versuch einer Monographie der Tichorhinen Nashörner nebst Bemerkungen über Rhinoceros leptorhinus Cuvier u.s.w. - Mémoires de l'Académie Impériale des Sciences de St.-Pétersbourg, s. 7, XXIV(4), pp. 1-135, Sankt Peterburg.

Chersky, I.D. 1874: Opisanie cherepa nosoroga, razlichnago ot' Rhinoceros tichorhinus (Description of a rhinoceros skull different from Rhinoceros tichorhinus) (in Russian). - Zapiski Imperatorskoy Akademii Nauk', XXV, pp. 65-75, Sankt Peterburg.

Chersky, I.D. 1891: Opisanie kollekzii posletretichnykh" mlekopitayushchikh" zhivotnykh", sobrannykh" Novo-Sibirskoyu Ekspedizieyu 1885-1886 g. (Description of the post-tertiary mammals collected by the new Siberian expedition in 1885-1886) (in Russian). - Prilozhenie k LXV-mu Tomu, Zapisok" Imperatorskoy Akademii Nauk, 65(1), pp. 1-706, Sankt Petersburg.

Dubrovo, I.A. 1957: Ob ostatkakh Parelephas wüsti (M. Pavl.) i Rhinoceros mercki Jaeger iz Yakutii (On remains of Parelephas wüsti [M. Pavl.] and Rhinoceros mercki Jaeger from Yakutya) (in Russian).Byulleten' Komissii po Izuchenyu Chetvertichnogo Perioda, 21, pp. 97-104, Izd-vo AN SSSR, Moskva/Leningrad.

Flerov, K.K., B.A. Trominov, N.M. Yanoskaya 1955: Istorya fauny mlekopitayushchikh v chetvertichnom periode (History of mammalian fauna in the Quaternary period) (in Russian). - Akademya Nauk SSSR (Geologichesky Muzey), 40 pp, 37 figs, Moskva.

Freidel, E. 1880: Ein Leichnam von Rhinoceros merckii aus Sibirien. - Der Zoologische Garten, Jhg 21, pp. 353-359, Frankfurt/M.

Gromov, V.I. 1933: Izuchenie chetvertichnoy fauny Severnogo Kavkaza (Study of the Quaternary fauna of Northern Caucasus) (in Russian). - Vestnik Akademya Nauk SSSR, 4, Moskva - Leningrad.

Gromov, V.I. 1939: Kratky sistematichesky i stratigrafichesky obzor chetvertichnykh mlekopitayushchikh (Brief systematic and stratigraphic review of the Quaternary mammals) (in Russian). - Vyp. 2, pp. 163-223, Sankt Peterburg.

Gromov, V.I. 1948: Paleontologicheskoe i arkheologicheskoe obosnavanie stratigrafii kontinental'nykh otlozheny chetvertichnogo perioda na territorii SSSR (Palaeontological and archaeological background for the stratigraphy of the continental Quaternary deposits on USSR territory) (in Russian). - Trudy Instituta Geologicheskoy Nauk AN SSSR (ser. Geologya), 64(17), pp. 1-524, Akademya Nauk SSSR, Moskva.

Gromova, V.I. 1932: Novye materialy po chetvertichnoy faune Povolzh'ya i po istorii mlekopitayushchikh Vostochnoy Evropy i Severnoy Azii voobshche (S prediesloviem prof. P.A. Pravoslavleva) (New material on the Quaternary fauna from Lower Volga and history of the mammals of Eastern Europe and Northern Asia in general [with a prologue by Prof. P.A. Pravoslavlev]) (in Russian, German abstract). Trudy Komissii po Izuchenyu Chetvertichnogo Perioda, II, pp. 69-184, Izd-vo Akademya Nauk SSSR, Leningrad.

Gromova, V.I. 1935: Ob ostatkakh nosoroga Mercka (Rhinoceros mercki Jaeg.) s Nizhney Volgi (Über die Reste des Merckschen Nashorn [Rhinoceros mercki Jaeg.] von der unteren Wolga) (in Russian, German abstract). - Trudy Paleozoologicheskogo Instituta AN SSSR, IV, pp. 91-136, Izd-vo Akademya Nauk SSSR, Moskva.

Gromova, V.I. 1965: Kratky obzor chetvertichnykh mlekopitayushchikh Evropy (Opyt sopostavlenya) (Brief review of the Tertiary mammals of Europe) (in Russian). - Komissia po Izuchenyu Chetvertichnogo Perioda, Akademya Nauk SSSR, Izd-vo "Nauka", Moskva, 143 pp. 
Khisarova, G.D. 1963: Iskopaemye kosti mlekopitayushchikh iz Koshkurganskogo grifona (Yuzhny Kazakhstan) (Mammalian osteological fossil remains from the Koshkurgan locality [Southern Kazakhstan]). - In: Materialy po Istorii Fauny i Flory Kazahstana) (in Russian). Akademya Nauk Kazakhskoy SSR (Institut Zoologii), Izd-vo "Nauka” KazSSR, 4, pp. 42-43, 48-51, Alma-Ata.

Kolbutov, A.D. 1935-1936: Geologicheskie nablyudenya v basseyne r. Kubani letom 1935 g. (Geological observations in the Kuban' river basin in summer 1935) (in Russian). - Institut Geologicheskoy Nauk, Akademya Nauk SSSR, Moskva, $137 \mathrm{pp}$.

Kozhamkulova, B.S., N.N. Kostenko 1984: Vymershie zhivotnye Kazahstana (Extinct animals of Kazakhstan). - In: Paleogeografya Pozdnego Kaynozoya (in Russian). Akademya Nauk Kazakhskoy SSR (Zoologicheskogo Instituta), Izd-vo "Nauka" KazSSR, Alma-Ata, p. 54.

Kretzoi, M. 1942: Präokkupierte und durch ältere zu ersetzende Säugetiernamen. - Földtani Közlöny, 72(4-12), pp. 345-349, Budapest.

McKenna, M.C., S.K. Bell 1997: Classification of Mammals above the Species Level. - Columbia University Press, New York, $631 \mathrm{pp}$.

Pavlova, M.V. 1933: Fauna mlekopitayushchikh sobrannykh v b. Saratovskoy gub., bliz g. Khvalynska na beregu r. Volgi (Faune des mammifères fossiles trouvès dans l'ancien gouvernement de Saratov près de la ville de Khvalinsk au bord du Volga) (in Russian). - Trudy Komissii po Izuchenyu Chetvertichnogo Perioda, 3(1), pp. 171-172, Leningrad.

Pusch, G.G. 1836: Geognostische Beschreibung von Polen sowie der übrigen Nordkarpathen-Länder. Stuttgart - Tübingen, Bd. II, 695 pp.

Salov, I.N. 1957: Nakhodki iskopaemoy chetvertichnoy fauny v Smolenskoy oblasti (Finds of fossil Quaternary fauna in the Smolensk region) (in Russian). - Smolensky Oblastnoy Kraevedchesky Muzey, 2, pp. 311-333, Smolensk Knizhnoe Izd-vo, Smolensk.

Schrenck, L. v. 1880: Der erste Fund einer Leiche von Rhinoceros merckii. - Zapiski Imperatorskoy Akademii Nauk, s. 7, 28(7), pp. 1-55, Sankt Peterburg.

Shpansky, A.V., E.M.E. Billia 2012: Records of Stephanorhinus kirchbergensis (Jäger, 1839) (Mammalia, Rhinocerotidae) from the Ob' River at Krasny Yar (Tomsk region, southeast of Western Siberia) (with Russian abstract). - Russian Journal of Theriology, 11(1), pp. 47-55, Moskva.

Strizheva, I.M. 1991: Kostnye ostatki krupnykh mlekopitayushchikh v rayone Samarskoy Luki (Osteological remains of large mammals from the Samara Luka district) (in Russian). - Samarskaya Luka, 2, pp. 197-205, Samara.

Svitoch, A.A., T.A. Yanina 1997: Chetvertichnye otlozhenya poberezhiy Kaspiyskogo Morya (Quaternary deposits on the Caspian sea banks) (in Russian). - Izd-vo Moskovskogo Gosuniversiteta, Moskva, 268 pp.

Vereshchagin, N.K. 1959: Mlekopitayushchie Kavkaza - Istorya Formirovanya Fauny (Mammals of Caucasus - History of the Faunal Formation) (in Russian). - Akademya Nauk Azerbayjanskoy SSR, Izd-vo Akademya Nauk SSSR, Moskva - Leningrad, 703 pp.

Woodward, H.M. 1881: A fossil rhinoceros in the flesh. - Geological Magazine, (2), 8, p. 96, London. 